\title{
CHONDROMYXOID FIBROMA OF C1: FIRST CASE REPORT
}

\author{
FIBROMA CONDROMIXÓIDE DE C1: PRIMEIRO RELATO DE CASO \\ FIBROMA CONDROMIXOIDE DE C1: PRIMER CASO
}

Ericson Sfreddo ${ }^{1}$, Asdrubal Falavigna ${ }^{2}$, Vinícius Borges Soares ${ }^{3}$, Silvia Chaves e Silva, ${ }^{4}$ André Nesi ${ }^{5}$, Vinícius Carraro do Nascimento ${ }^{6}$,

Pedro Guarise da Silva ${ }^{7}$

\begin{abstract}
Background: Chondromyxoid fibroma (CMF) is a rare, benign primary bone tumor. The cervical spine is an uncommon site for this tumor, with only 10 reported cases to date and none involving the first cervical vertebra (C1). Case Report: Female patient, 25-year-old monozygotic female twin, presented with cervical pain. Radiographic imaging demonstrated a contrast-enhanced, right-sided lytic lesion of the insufflated type in $\mathrm{C} 1$, with a punched-out appearance and extending to the anterior arch. A postero-lateral and a posterior approach were performed in two steps to resect the tumor followed by occipitocervical fixation. Pathology confirmed the diagnosis of CMF. At one year, the patient remains disease free with excellent spinal stability. Conclusion: Spinal surgeons may need to treat rare spinal tumors. Despite the proximity to neural and vascular structures, the goal of surgery is always a radical resection due to high recurrence rates.
\end{abstract}

Keywords: Cervical spine; Chondromyxoid fibroma; Bone tumor.

\section{RESUMO}

Revisão: O fibroma condromixóide (FCM) é um tumor ósseo primário, benigno e raro. A coluna cervical é um local incomum desse tumor, com apenas 10 casos relatados, sendo que nenhum envolveu a primeira vértebra cervical (C1). Relato do Caso. Paciente do sexo feminino, 25 anos, gêmea monozigótica, apresentando dor cervical. A imagem radiográfica demonstrou lesão lítica contrastada, predominantemente na massa lateral de $\mathrm{C} 1 \mathrm{com}$ extensão para o arco posterior e anterior. A ressecção do tumor foi feita em dois tempos, inicialmente uma abordagem postero-lateral, seguida pela via posterior. Nesta última, foi relizada uma fixação occiptocenical. O exame anátomo-patológico foi compatível com FCM. Passado um ano dos procedimentos, a paciente permanecia sem doença e com estabilidade craniocervical. Conclusão. Especialistas de coluna devem ter o conhecimento de que estes tumores raros podem acometer a coluna vertebral e, apesar da sua proximidade com tecido neural e estruturas vasculares, o objetivo da cirurgia é a sua ressecção radical devido ao alto índice de recidiva.

Descritores: Coluna cervical; Fibroma condromixoide; Tumor ósseo.

\section{RESUMEN}

Revisión: El fibroma condromixoide (FCM) es un tumor óseo primario, benigno y raro. La columna cervical es un lugar raro de este tumor, con solamente 10 casos relatados, siendo que ninguno involucra a la primera vértebra cervical (C1). Relato del Caso: Paciente del sexo femenino, 25 años, gemela monozigótica, presentando dolor cervical. La imagen radiográfica demostró una lesión contrastada, predominantemente en la masa lateral de C1 con extensión hacia el arco posterior y anterior. La resección del tumor se realizó en dos tiempos, inicialmente una aproximación posterolateral, seguida por la vía posterior. En esta última, se realizó una fijación occipitocervical. El análisis anatomopatológico fue compatible con FCM. Pasado un año de los procedimientos, la paciente permanecía sin enfermedad y con estabilidad cranio-cervical. Conclusión: Especialistas de columna deben tener el conocimiento de que estos tumores raros pueden acometer a la columna vertebral y, a pesar de su proximidad con el tejido neural y las estructuras vasculares, el objetivo de la cirugía es su resección radical debido al alto índice de recidiva.

\section{Descriptores: Columna cenical; Fibroma condromixoide; Tumor óseo}

\section{INTRODUCTION}

Chondromyxoid fibroma (CMF) is a rare benign tumor of the bone derived from cartilage precursor elements ${ }^{1}$. The spine is an uncommon primary site with only 10 cases of CMF in the cervical spine reported to date ${ }^{1-9}$. However, there are no reports of CMF involving the first-cervical $(\mathrm{C} 1)$ vertebra. We report the first case of CMF in $\mathrm{C} 1$, treated with a postero-lateral and posterior surgical approach.

\section{CASE REPORT}

A 25-year-old monozygotic female twin presented with two years of upper cervical pain and impaired mobility, especially when turning her head to the right side. On physical examination, lateral neck rotation and range of motion was restricted but there was no tenderness or mass on palpation. Neurological examination revealed no significant findings. Computed tomography (CT) scan and magnetic resonance imaging (MRI) both demonstrated a contrast-enhancing Iytic lesion of the insufflated type, with a punched-out appearance, located at the right lateral aspect of $\mathrm{C} 1$ and extending to the anterior arch (Figure 1).

A CT-guided needle biopsy was performed using a postero-lateral approach but the tumor material was insufficient for the pathological

1. Neurosurgeon, Hospital Cristo Redentor - Grupo Hospitalar Conceição, Porto Alegre, Brazil.

2. Professor of Neurosurgery, University of Caxias do Sul, Caxias do Sul RS, Brazil.

3. Resident in Neurosurgery, Hospital Cristo Redentor - Grupo Hospitalar Conceição, Porto Alegre, Brazil

4. Pathologist, Grupo Hospitalar Conceição, Porto Alegre, Brazil

5. Resident in Neurosurgery, Hospital Cristo Redentor - Grupo Hospitalar Conceição, Porto Alegre, Brazil

6. Medical Student, Universidade Federal de Ciências da Saúde de Porto Alegre, Porto Alegre, Brazil

7. Medical Student, University of Caxias do Sul, Caxias do Sul, RS, Brazil. 
examination. Based upon the location, size and extent of the lesion, a postero-lateral surgery was planned to achieve radical resection and fixation. The need for posterior fixation was anticipated.

A postero-lateral approach was performed to expose the C1 vertebra (procedure described previously) ${ }^{10}$. The lesion was soft, in some parts containing liquid, tan-colored, and well-vascularized. The anterior and lateral portion of the mass of $\mathrm{C} 1$ and the anterior arch through the midline could be resected in block, but the posterior portion of the lateral mass of the $\mathrm{C} 1$ was partially resected by aspiration and curettage. The technical difficulties to remove the posterior portion of the tumor completely changed the surgical plan and it was found necessary to use a posterior approach. An iliac bone graft was implanted in the resection bed to achieve initial stability. Blood loss was $400 \mathrm{ml}$ and operative time was 3 hours. Pathology showed stellar neoplastic cells with an increased number of pleomorphic nuclei and myxoid matrix that were diagnostic of CMF (Figure 2).

The residual posterior tumor was resected one week later through a posterior approach. An occipitocervical fixation was performed using the Occifix ${ }^{\circledR}$ system, GMReis ${ }^{\text {TM }}$, and iliac bone graft. The C2 pedicle screw was not firm so it was decided to extend the fixation to C4 (Figure 3B). Blood loss in the second surgery was $300 \mathrm{ml}$ and operative time was 2.5 hours. A 30-day postoperative CT demonstrated complete resection of the lesion with stable occipitocervical fixation (Figure 3A). At 1-year follow-up there was a calcified region between the lateral mass of $\mathrm{C} 1$ and the odontoid process (Figure $3 C)$. Clinically, preservation of $50 \%$ lateral neck rotation bilaterally was achieved and the patient was pain-free without without compromising the neurological aspects at 1-year follow-up.
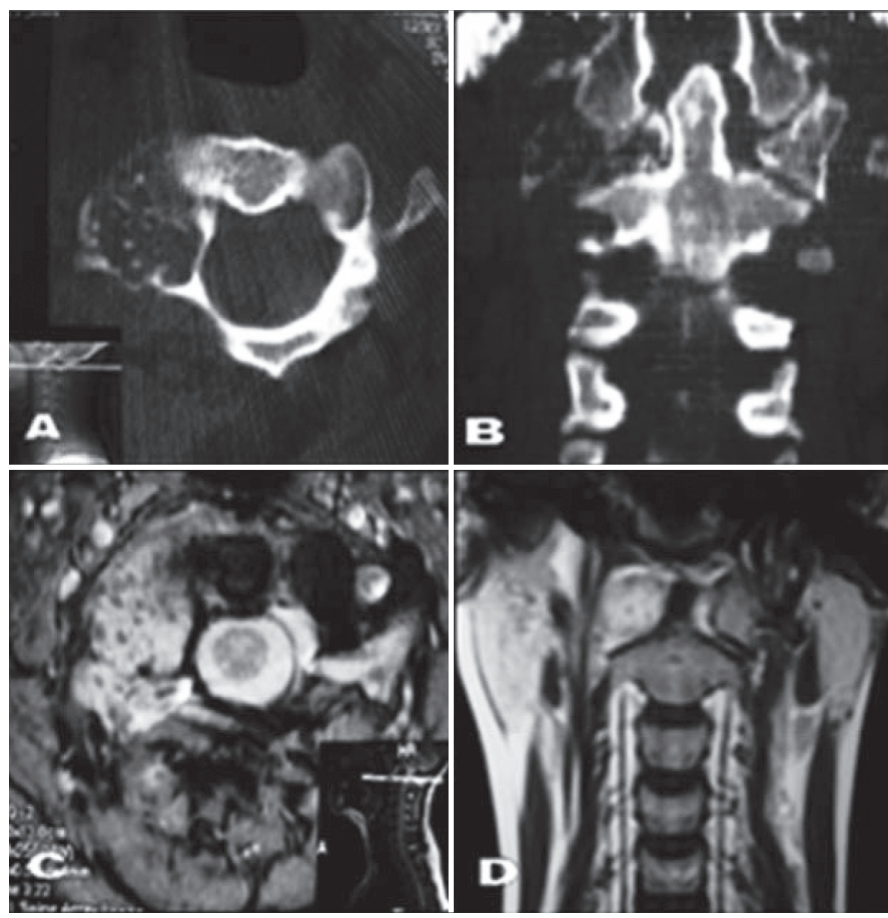

Figure 1. Axial CT images showing: (A). Lesion of the right lateral mass of $\mathrm{C} 1$ insufflating the bone and partially maintaining cortical integrity. (B). Destruction of the atlantoaxial articulation by tumor. (C). T2-weighted MR with gadolinium in axial view. (D). Coronal view.

\section{DISCUSSION}

The first case report published on CMF was in 1948 by Jaffe and Lichtenstein ${ }^{11}$. CMF is a benign tumor characterized by lobulated areas, spindle-shaped or stellate cells, and abundant chondroid or myxoid material. Central portions of the tumor have greater cellularity and heterogeneous population of multinuclear giant cells $s^{1,5}$. The metaphysys of the long bones is the most common primary site; vertebral involvement is uncommon and occurs in only $8 \%$ of cases ${ }^{12}$

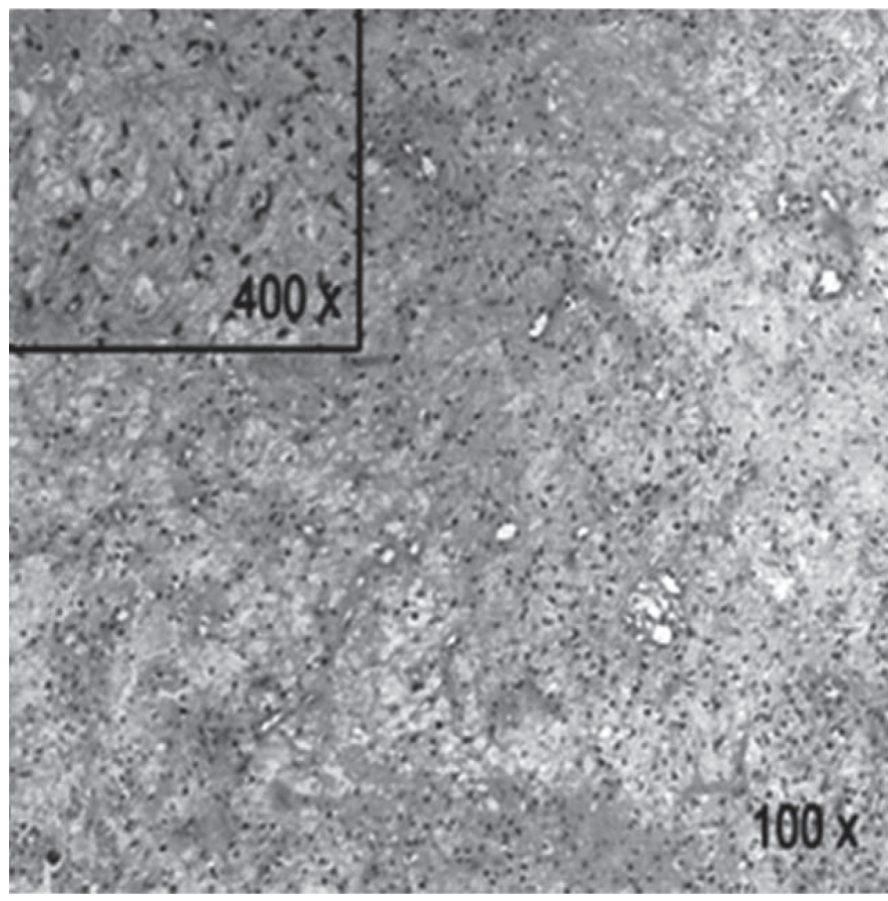

Figure 2. CMF myxoid matrix (hematoxylin-eosin stain, $100 \mathrm{x}$ ). Detail of stellate cells (hematoxylin-eosin stain, $400 \mathrm{X}$ ).
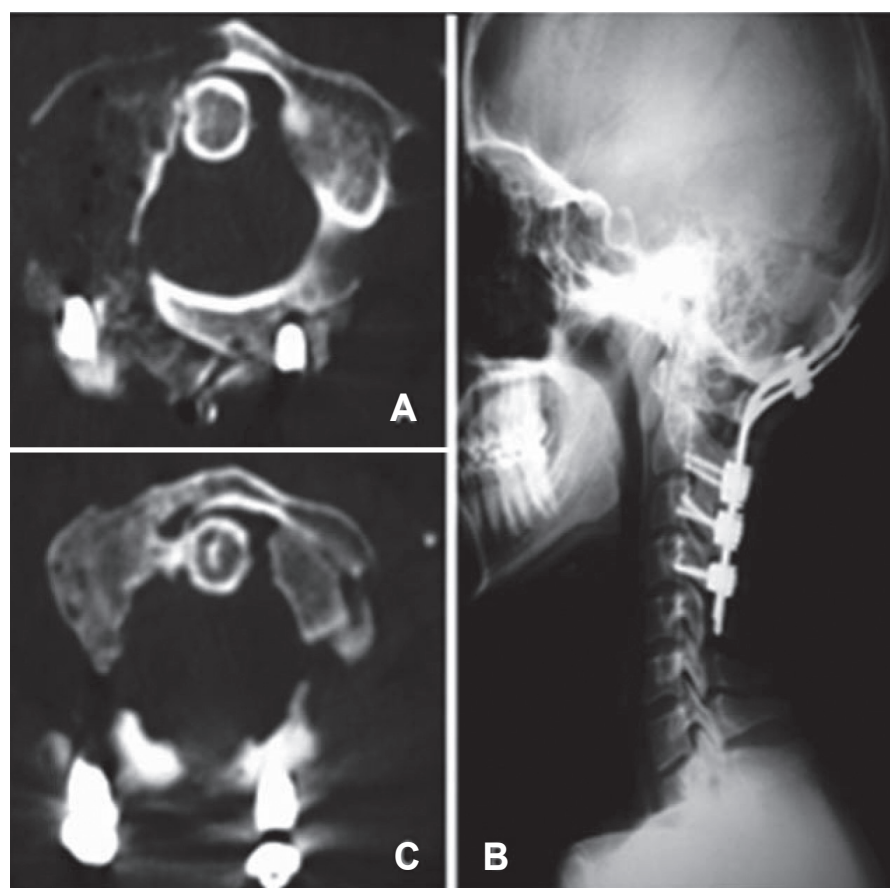

Figure 3. Axial CT images of: (A). A 30-day postoperative CT demonstrated resection of the lesion and some postoperative residual liquids. (B) Occipitocervical fixation. (C). One year postoperatively, with calcification of the lateral mass and osteogenesis between the $C 1$ lateral mass and odontoid process.

Only 10 cases involving the cervical spine have been reported, none in $\mathrm{C} 1$ (Table 1) $^{1-9}$. A female preponderance was observed in patients with cervical spinal CMF, with C2 being most commonly affected. The most common clinical manifestation reported was neck pain ${ }^{12}$ 13. Radiologically CMF appears as a well-defined Iytic lesion with lobulated margins, a sclerotic ring, and septations. Occasionally, periosteal extension may occur due to fusiform expansion of the bone and calcifications are uncommon ${ }^{13}$ 
Table 1. Reported cases of cervical spinal chondromyxoid fibroma

\begin{tabular}{|c|c|c|c|c|}
\hline Cases & $\begin{array}{c}\text { Age/ } \\
\text { Gender }\end{array}$ & Level & Management & $\begin{array}{l}\text { Follow-up } \\
\text { (months) }\end{array}$ \\
\hline Schajowicz et al, $(1971)^{9}$ & $6 / F$ & C3 & Resection & $48, N R$ \\
\hline Standefer et al, $(1982)^{3}$ & $20 / F$ & C7 & $\begin{array}{l}\text { Irradiation, posterior } \\
\text { decompression, } \\
\text { anterior resection }\end{array}$ & $15, N R$ \\
\hline Provelegios et al, $(1988)^{8}$ & $32 / \mathrm{M}$ & C4 & $\begin{array}{c}\text { Anterior curettage, } \\
\text { bone graft }\end{array}$ & $10, N R$ \\
\hline Zillmer et al,(1989) & $20 / F$ & $\mathrm{C} 7$ & Resection, radiotherapy & $84, \mathrm{MR}$ \\
\hline Rivierez et al, $(1991)^{6}$ & $41 / F$ & C5 & $\begin{array}{c}\text { Posterior decompres- } \\
\text { sion, anterior curettage } \\
\text { and bone graft }\end{array}$ & $30, N R$ \\
\hline Wu et al, $(1998)^{5}$ & \multicolumn{2}{|c|}{ Not reported } & Curettage/excision & \\
\hline Lopez-Ben et al, $(2002)^{1}$ & 20/M & $\mathrm{C} 2$ & \begin{tabular}{|c|}
$\begin{array}{c}\text { Transoral vertebrectomy, } \\
\text { posterior fusion }\end{array}$ \\
\end{tabular} & $24, N R$ \\
\hline Bala et al, $(2006)^{2}$ & $36 / \mathrm{M}$ & C2 & $\begin{array}{c}\text { Transoral curettage, } \\
\text { anterior fixation }\end{array}$ & $6, N R$ \\
\hline Subach et al, $(2010)^{4}$ & $27 / F$ & C6 & $\begin{array}{c}\text { Laminectomy, resection, } \\
\text { postero-lateral fusion } \\
\text { at C5-C7. }\end{array}$ & \\
\hline Our case & $25 / F$ & C1 & $\begin{array}{c}\text { Far-lateral curettage, } \\
\text { posterior curettage and } \\
\text { occipitocervical fixation }\end{array}$ & $12, N R$ \\
\hline
\end{tabular}

NR - No Recurrence; MR - Malignant Recurrence

The radiological exam can be useful to try to differentiate benign chondroid tumors from malignant chondroid tumors in the preoperative period. The radiography has been the most frequently used imaging modality in the studies ${ }^{14}$. The typical radiographic appearance of a benign chondroma is described as saucerization of the adjacent cortex, with a well-formed sclerotic periosteal reaction. A soft-tissue mass is not frequently shown, and matrix calcification occurs in approximately $50 \%$ of patients ${ }^{15,}{ }^{16}$. Malignant lesions are typically larger, more ill-defined, and may show medullary extension ${ }^{15,}{ }^{17}$. However, it is indispensable to correlate them with the clinical and pathological findings, since periosteal chondromas may have an aggressive radiographic appearance and small chondrosarcomas may appear radiologically benign. ${ }^{15,}{ }^{16}$ Aneurismal bone cysts might also on some occasions be indistinguishable on radiography ${ }^{18}$.

The differential diagnosis of CMF includes chondrosarcoma, chondroblastoma, aneurysmal bone cyst, giant cell tumor, osteoblastoma, and fibrous dysplasia (FD) ${ }^{5}$. CMF is difficult to distinguish from chondrosarcoma histologically, because peripheral nuclear condensation and cental hypercellularity can be seen in both. While diagnostic distinction from chondrosarcoma is important, resection remains the mainstay of treatment in both. CMF may also be confused with FD due to the presence of myxoid elements, especially if no lobulations are presented ${ }^{5}$. One of the challenges in treating CMF is that a symptomatic spinal mass is approached as malignant, with the goal of being complete resected and fusion when necessary, as in this case $\mathrm{c}^{9,11,13}$. Sometimes complete tumor resection is not possible because of the proximity to a neural or vascular structure and in such cases surgeons should perform other types of surgical approach when possible, as in this case, in order to try to remove as much is possible.

Tumor recurrence after surgical treatment may occur in 4 to $20 \%$ of cases ${ }^{9,12,19}$, more commonly in younger patients ${ }^{9,11}$. Most recurrences (up to $80 \%$ with a 30 year follow-up) occur when curettage alone (and not in bloc resection) is performed ${ }^{7}, 9,14,20$. Radiotherapy is not recommended but has been attempted with complications (radionecrosis, osteomyelitis, and sarcomatous transformation) $)^{5,9,12}$.

\section{CONCLUSION}

CMF is a rare benign tumor derived from cartilage precursor elements. Despite the proximity to neural and vascular structures a radical resection is preferred due to high postoperative recurrence.

\section{REFERENCES}

1. Lopez-Ben R, Siegal GP, Hadley MN. Chondromyxoid fibroma of the cervical spine: case report. Neurosurgery. 2002;50:409-11.

2. Bala A, Robbins P, Knuckey N, Wong G, Lee G. Spinal chondromyxoid fibroma of C2. J Clin Neurosci. 2006;13:140-6.

3. Standefer M, Hardy RW, Jr., Marks K, Cosgrove DM. Chondromyxoid fibroma of the cervical spine-a case report with a review of the literature and a description of an operative approach to the lower anterior cervical spine. Neurosurgery. 1982;11:288-92.

4. Subach BR, Copay AG, Martin MM, Schuler TC, Romero-Gutierrez M. An unusual occurrence of chondromyxoid fibroma with secondary aneurysmal bone cyst in the cervical spine. Spine J. 2010;10:e5-9.

5. Wu CT, Inwards CY, O'Laughlin S, Rock MG, Beabout JW, Unni KK. Chondromyxoid fibroma of bone: a clinicopathologic review of 278 cases. Hum Pathol. 1998;29:438-46.

6. Rivierez M, Richard S, Pradat P, Devred C. Chondromyxoid fibroma of the cervical spine. Apropos of a case treated by partial vertebrectomy. Neurochirurgie. 1991;37:264-8.

7. Zillmer DA, Dorfman HD. Chondromyxoid fibroma of bone: thirty-six cases with clinicopathologic correlation. Hum Pathol. 1989:20:952-64.

8. Provelegios S, Markakis P, Markaki S. Chondromyxoid fibroma with spinal cord compression. Neuroorthopedics. 1988:49-52.

9. Schajowicz F, Gallardo H. Chondromyxoid fibroma (fibromyxoid chondroma) of bone. A clinico-pathological study of thirty-two cases. J Bone Joint Surg Br. 1971:53:198-216.

10. al-Mefty O, Borba LA, Aoki N, Angtuaco E, Pait TG. The transcondylar approach to extradural nonneoplastic lesions of the craniovertebral junction. J Neurosurg. 1996;84:1-6.

11. Jaffe $\mathrm{HL}$, Lichtenstein $\mathrm{L}$. Chondromyxoid fibroma of bone; a distinctive benign tumor likely to be mistaken especially for chondrosarcoma. Arch Pathol (Chic). 1948;45:541-51.

12. Spjut HJ, Dorfman HD, Fechner RE. Tumors of Bone and Cartilage: Atlas of Tumor Pathology. Washington DC: Armed Forces Institute of Pathology; 1971.

13. Feldman $F$, Hecht $H L$, Johnston AD. Chondromyxoid fibroma of bone. Radiology. 1970;94:249-60.

14. Robinson P, White LM, Sundaram M, Kandel R, Wunder J, McDonald DJ, et al. Periosteal chondroid tumors: radiologic evaluation with pathologic correlation. AJR Am J Roentgenol. 2001;177:1183-8

15. Nojima T, Unni KK, McLeod RA, Pritchard DJ. Periosteal chondroma and periosteal chondrosarcoma. Am J Surg Pathol. 1985;9(9):666-77.

16. Boriani S, Bacchini P, Bertoni F, Campanacci M. Periosteal chondroma. A review of twenty cases. J Bone Joint Surg Am. 1983:65:205-12.

17. Brien EW, Mirra JM, Luck JV, Jr. Benign and malignant cartilage tumors of bone and joint: their anatomic and theoretical basis with an emphasis on radiology, pathology and clinical biology. II. Juxtacortical cartilage tumors. Skeletal Radiol. 1999:28:1-20.

18. Ralph LL. Chondromyxoid fibroma of bone. J Bone Joint Surg Br. 1962:44-B:7-24

19. Kikuchi F, Dorfman HD, Kane PB. Recurrent chondromyxoid fibroma of the thoracic spine 30 years after primary excision: case report and review of the literature. Int J Surg Pathol. 2001:9:323-9.

20. Gherlinzoni F, Rock M, Picci P. Chondromyxoid fibroma. The experience at the Istituto Ortopedico Rizzoli. J Bone Joint Surg Am. 1983;65:198-204. 